\title{
Application of Accentuated Eccentric Loading to Elicit Acute and Chronic Velocity and Power Improvements: A Narrative Review
}

\author{
Justin J. Merrigan, $\mathrm{PhD}^{1}$, Jonathon Borth, $\mathrm{MS}^{2}$, Christopher B Taber, $\mathrm{PhD}^{3}$, Timothy J. Suchomel, $\mathrm{PhD},{ }^{4}$, \\ Margaret $\mathrm{T}$. Jones, $\mathrm{PhD}^{5}$
}

${ }^{1}$ Human Performance Collaborative, Office of Research, The Ohio State University, Columbus, OH, United States, West Virginia University, Morgantown, WV, USA, ${ }^{2}$ College of Education and Human Development, George Mason University, Fairfax, Virginia, ${ }^{3}$ Department of Physical Therapy and Human Movement Science, Sacred Heart University, Fairfield, CT, USA, ${ }^{4}$ Department of Human Movement Sciences, Carroll University, Waukesha, WI, USA, ${ }^{5}$ School of Sport, Recreation, and Tourism Management, George Mason University, Fairfax, Virginia

\section{ABSTRACT}

Accentuated eccentric loading (AEL) employs heavier load magnitudes in eccentric actions than concentric actions of complete stretch-shortening cycles. In doing so, unique neuromuscular and molecular responses are expected to result in acute post-activation performance enhancements, as evidenced by increased movement velocity or power. Improvements are dependent upon load selection, which varies across exercises, such as jumps and bench press throws (eccentric: 20$40 \mathrm{~kg}$ or $20-30 \%$ of body mass; concentric: body mass only), and squats and bench press (eccentric: 77.3-120\% One-Repetition Maximum (1-RM); concentric: $30-90 \% 1-R M)$. The efficacy of AEL is dependent upon the concentric load used, which in turn is influenced by the magnitude of the eccentric load. Greater strength relative to body mass may enable the maintenance of technique and pacing during AEL, necessary for resultant performance enhancements, particularly when using eccentric loads exceeding the individual's concentric 1-RM. Before prescribing AEL practitioners should consider: training experience, strength relative to body mass, the particular exercise, AEL application method, and the magnitude of both eccentric and concentric loads. Thus, the aims of this brief review are to describe: 1) neuromuscular and molecular constructs of AEL; 2) acute effects of AEL; 3) chronic effects of AEL; 4) loading considerations; 5) practical applications.

Key Words: Eccentric training; Augmented eccentric loading; Post-activation performance enhancement; Velocity-based training; Power training

\section{INTRODUCTION}

As a result of their $50 \%$ greater force production capability than concentric actions (Figure 1), eccentric actions possess unique neural, molecular, and metabolic responses [1-3]. Thus, traditional loading, where the eccentric and concentric loading magnitudes are equivalent, likely does not maximize the force producing potential of the muscle. Resultantly, eccentric overloading methods have been developed, such as forced eccentric repetitions, supramaximal concentric loading, and accentuated eccentric loading (AEL). Forced eccentric repetitions are performed once 
an individual is unable to complete concentric actions, resulting in further motor unit recruitment due to muscular failure of lower level motor units [4-6]. Supramaximal concentric loading refers to performing only the eccentric portion of a lift with a load greater than concentric one-repetition maximum (1-RM) and has shown strength and power adaptations similar to traditional loading methods [7]. However, these methods, commonly referred to as "negatives", have potential flaws when the training purpose is to enhance explosiveness (i.e., concentric velocity or power), as neither include the entire stretch-shortening cycle. Accentuated eccentric loading implements greater loads during the eccentric action that are released prior to the concentric action within a complete stretchshortening cycle. Due to the inherent flaws in previous methods, AEL is uniquely positioned as it does not interrupt natural mechanics and permits utilization of the stretch-shortening cycle [8].

The magnitude of eccentric loading prescribed during AEL may be less than (i.e., submaximal $A E L$ ), equal to (maximal $A E L$ ), or greater than the concentric 1-RM (i.e., supramaximal AEL). Greater subsequent concentric (also referred to as propulsive) performances may result from the selective recruitment of high threshold motor units [9] or greater elastic potentiation (i.e., muscle spindles and reflex loops) if eccentric actions are performed at a faster rate [10-12]. However, to elicit neuromuscular responses and practical benefits from utilization of the stretch shortening cycle, concentric actions must be performed immediately after eccentric actions. For example, an individual may overload the eccentric action with a fast transition to concentric actions by performing countermovement jumps while holding dumbbells during the eccentric portion and releasing them before transitioning to perform the jump. Other methods may include the use of weight releasing devices (explained in greater detail later in this review) that disengage from the barbell when transitioning between the eccentric to concentric portions of the exercise. Physiological benefits to AEL include: shifts to faster myosin heavy chain isoforms and increases in IIx muscle cross sectional area, muscle fiber lengthening, and high threshold motor unit activation $[8,13,14]$. Due to these neurological and morphological adaptations, some have found AEL to be a beneficial means for improving velocity, force, or power during resistance training movements [14-21], as well as explosive jumping and throwing tasks [22-27]. Currently, the literature related to prescription of $A E L$ is inconclusive due to the wide range of participant training experience, exercise selection, load prescriptions, method of AEL, and performance variables analyzed [13-23,25,28-32].

Therefore, to assist strength and conditioning practitioners and scientists, the current brief review will cover the following in regard to AEL: 1) physiological framework and the role of prior strength training experience; 2) acute effects on explosive power during jumps and bench throws; 3) acute effects on explosive power during squat and bench press exercises; 4) acute and chronic postexercise effects; 5) explanation of different loading considerations; 6) practical applications.

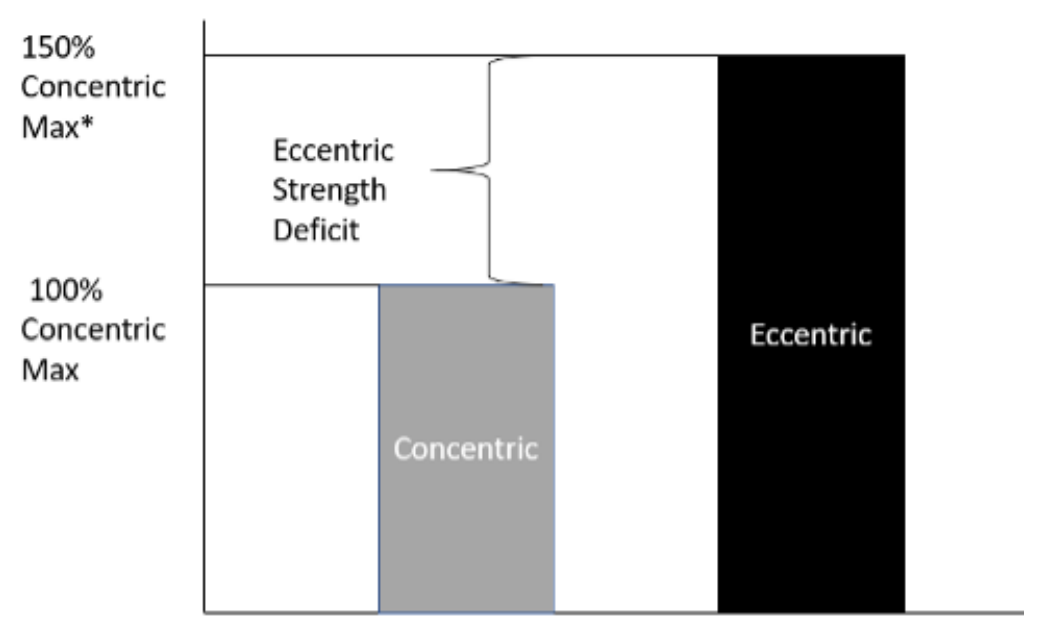

*Theoretical max. Not tested

Figure 1. Example of strength deficit between eccentric and concentric actions. 


\section{PHYSIOLOGICAL SUPPORT AND THE ROLE OF PRIOR STRENGTH TRAINING EXPERIENCE}

The uniquely reduced motor unit recruitment [33-36] and firing rates [37-39] during eccentric actions, compared to similarly loaded concentric actions, support the rationale for use of heavier eccentric loads during AEL. The primary premise is that disproportionately overloading the eccentric action will increase muscle activity to be equivalent to that of the concentric action [40]. However, the increased muscle activity and forces during the eccentric action may not always be enough to potentiate concentric performances [28].

One potential explanation is that the differences in electromyography readings between eccentric and concentric actions are smaller in untrained individuals than those accustomed to resistance training $[33,37,41]$. The lower neuromuscular conditioning in untrained individuals may inhibit the improved gaps in muscle activity between muscle actions due to the difficulty of reaching maximal force production during eccentric actions [34]. Since faster velocities of muscle lengthening may further promote the preferential recruitment of whole muscle with more fast twitch motor units and muscle fibers $[42,43]$, untrained individuals may also struggle to benefit from $A E L$ if they require slower pacing strategies to control the heavier eccentric loading. Moreover, during overloaded eccentric actions there may be protective inhibitory mechanisms of reduced motor neuron responsiveness as a result of Golgi tendon organs being triggered to protect against potential damage to the muscle-tendon unit $[41,44]$. Although others have suggested minimum contributions exist from Golgi tendon organs $[37,45]$ or reciprocal inhibition $[46,47]$, it is unknown whether these protective mechanisms exist when using supramaximal concentric loads during AEL with free weight exercises. These mechanisms are also more likely to be contributors for untrained individuals, but the magnitude and severity of these inhibitory actions are likely reduced over time from heavy resistance training experience $[37,45]$. Thus, bringing to question whether the use of supramaximal AEL is necessary or beneficial for untrained or lesser trained populations.

One unique molecular strategy during muscle lengthening is the activation of the second myosin head, which may result in more active cross-bridge formations [48]. These cross-bridge formations are further increased, by mechanical conditions, such as faster rates of muscle lengthening [48]. However, passive mechanisms (e.g., series and parallel elastic components) also contribute to performance enhancement following maximal eccentric actions, beyond what can be explained by the active crossbridge theories of the contractile component [49]. Further, titin may increase passive forces in the I-band region of the sarcomere by acting as a stiff spring during muscle actions, directly relating to the length of the muscle fibers, and thus, strengthening the entire contractile component to help regulate and enhance muscle forces [49-53]. The interaction of titin during cross-bridge formation may also play a role in storing energy that is later used during active shortening muscle actions [54].

Cumulatively, the elastic responses and contractile component potentiation may contribute to the resultant concentric performance enhancement from AEL through stored elastic energy from parallel elastic component, series elastic component, and titin, as well as stimulated muscle spindle reflexes, Type la afferent nerves, and high threshold motor units [55]. Therefore, the efficacy of AEL may be dictated by the magnitude of differences between eccentric and concentric loads [19]. However, when performing additional repetitions following an AEL repetition, AEL may increase rates of muscle lengthening and potentiate concentric actions [19] through activation of higher threshold motor units [9] and preserved elastic energy [55,56]. Lastly, the aforementioned mechanisms may suggest that untrained or weaker individuals may not experience the potentiating effects of AEL, but further research is warranted.

\section{ACUTEEFFECTSOFACCENTUATEDECCENTRIC LOADING DURING JUMPS AND BENCH PRESS THROWS}

In general, AEL is implemented to potentiate concentric actions in terms of velocity and power performances of explosive exercises such as jumps and throws (Table 1) [16,20,24-26,31,57]. As previously mentioned, the efficacy of AEL for improving concentric performance may be dependent upon the rate of muscle lengthening. This has been demonstrated in the bench press throw, as greater throw heights were achieved with AEL $(+20-$ $40 \mathrm{~kg}$ of additional bar mass) by reaching greater accelerations [27]. However, this was conducted using a Smith machine, which has a fixed bar path that is different than free weights [58]. During jump squats with $30 \%$ back squat $1-\mathrm{RM}$, AEL with an additional 20,50 , or $80 \%$ of the back squat $1-\mathrm{RM}$ 
failed to elicit changes in jump squat performances of resistance-trained men [31]. However, no information was provided on the velocity of the eccentric actions. It is likely that the heavy eccentric loads required subjects to use slower pacing strategies during the eccentric and amortization phases which may negate potentiation effects due to dissipated elastic energy $[10,56]$. Further evidence of optimal loading was noted when an additional load of $20 \%$ body mass elicited greater countermovement jump performances than additional loads of $10 \%$ and $30 \%$ body mass during drop jumps with AEL [24]. Thus, to optimize the effects of AEL on subsequent explosive performances, controlling for a minimum disruption to exercise technique and movement mechanics may be necessary.

When utilizing elastic bands to implement AEL (i.e., $20 \%$ or $30 \%$ of body mass), countermovement jump performances were improved with 30\% compared to the control condition of bodyweight only [23]. Yet, these same procedures during drop jumps resulted in no jump height improvement, although earlier electromyography onsets were noted, along with greater eccentric (also referred to as braking) impulse and rate of force development during the $30 \%$ protocol [22]. Thus, the intensity of the drop jumps was greater for the AEL conditions, which may serve to increase the ability to accept external forces during high eccentric loading conditions, such as those experienced in sport and tactical populations
[59]. Others have attempted to account for individual variation in optimal drop height and reported AEL with $20 \%$ body mass elicited improved countermovement jump performances at 2- and 6-minutes, but not 12-minutes, which suggests that the potentiation dissipated after 6 minutes [24]. It is also important to note and consider the set up and function of the elastic bands for AEL resistance, as the band will be held or attached to the individual and provide full resistance at the top of the exercise (i.e., drop jump or countermovement jump). Thus, the elastic bands provide lower resistance throughout the eccentric action as the tension in the band is reduced. Since the drop jump begins at a higher position (from a box), it is likely that greater changes in tension will exist throughout the longer downward trajectory compared to countermovement jumps. Therefore, the elastic bands likely provide more consistent and greater tension during the countermovement jump, which may explain some discrepancies in findings when using elastic bands to execute AEL.

\section{ACUTE EFFECTS OF ACCENTUATED ECCENTRIC LOADING DURING THE SQUAT AND BENCH PRESS}

Although AEL is popular in traditional resistancetraining movements like the squat $[32,57,60]$ and bench press [20], evidence of its effectiveness is lacking (Table 2). Often with these exercises the

Table 1. Acute performance implications of accentuated eccentric loading in jumping and bench press throwing

\begin{tabular}{|c|c|c|c|c|}
\hline Movement & $\begin{array}{l}\text { Loading } \\
\text { Method }\end{array}$ & $\begin{array}{l}\text { Training Status / } \\
\text { Strength level }\end{array}$ & Load Magnitude & $\begin{array}{l}\text { Performance } \\
\text { Implications }\end{array}$ \\
\hline \multirow[t]{2}{*}{$\begin{array}{c}\text { Countermovement } \\
\text { Jump }\end{array}$} & Dumbbells & $\begin{array}{c}\text { Elite men volleyball } \\
\text { players }\end{array}$ & $\begin{array}{c}\text { ECC: } 20 \mathrm{~kg} \\
\text { CON: BM }\end{array}$ & $\begin{array}{l}\text { Improved jump } \\
\text { height [26] }\end{array}$ \\
\hline & $\begin{array}{l}\text { Resistance } \\
\text { band }\end{array}$ & $\begin{array}{c}\text { Men, Training } \geq 6 \text { months } \\
\text { Back squat } 1-R M \geq 2 x \\
\text { BM }\end{array}$ & $\begin{array}{c}\text { ECC: } 20 \& 30 \% \text { BM } \\
\text { CON: BM }\end{array}$ & $\begin{array}{c}\text { Increased ECC } \\
\operatorname{RFD}(30 \%>20 \%) \\
{[22]}\end{array}$ \\
\hline \multirow[t]{2}{*}{ Drop Jump } & $\begin{array}{l}\text { Resistance } \\
\text { band }\end{array}$ & Men, Training $\geq 6$ months & $\begin{array}{c}\text { ECC: } 30 \% \text { BM } \\
\text { CON: BM }\end{array}$ & $\begin{array}{l}\text { Increased jump } \\
\text { height [23] }\end{array}$ \\
\hline & Dumbbells & $\begin{array}{l}\text { Men, } \geq 2 \text { years plyo. exp. } \\
\text { Squat } 1-R M \geq 1.5 \times \mathrm{BM}\end{array}$ & $\begin{array}{l}\text { ECC: } 20 \% \text { BM } \\
\text { CON: BM }\end{array}$ & $\begin{array}{l}\text { Increased jump } \\
\text { height [24] }\end{array}$ \\
\hline Jump Squat & $\begin{array}{l}\text { Weight } \\
\text { Releaser }\end{array}$ & $\begin{array}{c}\text { Resistance trained men } \\
\text { Back squat } 1-\mathrm{RM} \geq 120 \% \\
\text { BM }\end{array}$ & $\begin{array}{c}\text { ECC: } 50 / 80 / 110 \% \\
\text { 1-RM } \\
\text { CON: } 30 \% 1-R M\end{array}$ & $\begin{array}{l}\text { No difference in } \\
\text { force, power, or } \\
\text { RFD [31] }\end{array}$ \\
\hline $\begin{array}{c}\text { Bench Press } \\
\text { Throw }\end{array}$ & $\begin{array}{l}\text { Weight } \\
\text { Releaser }\end{array}$ & $\begin{array}{c}\text { Bench 1-RM: 93-111 kg } \\
\text { Men members of a } \\
\text { national sports academy }\end{array}$ & $\begin{array}{c}\text { ECC: } 60,70,80 \mathrm{~kg} \\
\text { CON: } 40 \mathrm{~kg}\end{array}$ & $\begin{array}{c}\text { Increased bar } \\
\text { displacement [27] }\end{array}$ \\
\hline
\end{tabular}

ECC, eccentric action; CON, concentric action; BM, body mass; RFD rate of force development; 1-RM, one-repetition maximum 
concentric load is heavier than jumping or bench throws and therefore, requires a greater eccentric load that may subsequently alter the pacing strategy $[19,20,31,57]$. However, when controlling the eccentric pacing strategy by instructing participants to descend for 3 seconds during front squat exercise, AEL (105-120\% 1-RM) increased concentric force, velocity, and power of the same repetition compared to traditional loading (90\% 1-RM) [57]. Additionally, this study demonstrated that power improvement was greater from AEL with $120 \%$ compared to $105 \%$ 1-RM, indicating dependency upon the eccentric load used [57]. However, because the pacing strategy was controlled, these findings cannot be applied to uncontrolled environments. For example, in the back squat and bench press, AEL (eccentric:concentric load, 120\%: 50-80\% 1-RM) resulted in slower eccentric velocities, and subsequently slower or unaltered concentric velocities compared to traditional loading $[19,30]$.

Although the pacing strategy is likely slower during the eccentric action using AEL, some have found faster eccentric pacing strategies during multiple non-AEL repetitions following a single AEL repetition $[19,29,32]$. It is expected that faster eccentric velocities may result in the recruitment of high threshold motor units [9], enhanced stretchshortening reflexes [11], and greater muscle spindle activation [12], which subsequently potentiates concentric performances. Yet, AEL (105:80\% 1-RM) may increase eccentric rate of force development in the following non-AEL back squat repetitions, but may not influence concentric velocity and power [32]. In the back squat, increased eccentric velocities were noted in repetitions following an AEL repetition (120\% 1-RM) within the same set [19]. However, improvements in concentric performances were noted when using 65\% 1-RM, but not $80 \%$ 1-RM [19]. Although similar increases in eccentric velocities were noted with AEL of $120 \%$, concentric performances were unaffected using 65\% 1-RM in the bench press [30]. A possible reason for different findings between the bench press and back squat, is that the bench press covers a smaller range of motion and may not allow long enough duration under AEL. Collectively, these findings may suggest that the efficacy of $A E L$ is affected by the concentric load and that loading patterns differ between exercises. Yet, more research is necessary to determine whether it is the magnitude of the concentric load, or the magnitude of the difference between the eccentric and concentric loads that contributes to the efficacy of AEL.
Therefore, when using supramaximal concentric loads to implement AEL during the squat or bench press exercises, it is likely that pacing strategies will be slower and result in lower performances than traditional loading unless pacing is controlled. Yet, there is evidence to suggest that individuals with greater levels of strength are less likely to adopt slower pacing strategies as a result of the increased loads during the eccentric actions [30]. Since movement mechanics may be altered due to weight releasers during the bench press [28], it is possible stronger athletes are less negatively impacted by the weight releasers [30]. Further, recent evidence suggests that weight releasers do not have to be reloaded for every repetition $[19,30,32]$. This finding is beneficial for practitioners as the utilization of weight releasers can be cumbersome, although further research is necessary to identify optimal loading strategies. Lastly, due to increases in eccentric intensities without undue muscle damage responses [61], it is possible that low volume AEL may be used to progress those without prior exposure toward utilizing eccentric actions with heavier loads (i.e., higher volumes of AEL) or greater rates of muscle lengthening (i.e., plyometrics).

\section{ACUTE AND CHRONIC POST-EXERCISE EFFECTS OF ACCENTUATED ECCENTRIC LOADING}

The increased rate of eccentric actions (i.e., eccentric velocity), as noted during AEL $[19,19,60]$, may yield more post-exercise muscle damage than traditional loading [64]. It is not uncommon for individuals to respond to unaccustomed exercise with impaired muscle function [65], delayed onset muscle soreness [66], and increased muscle swelling or stiffness $[65,67]$. Thus, for untrained individuals, there may be more soreness in initial sessions of AEL training [68], which may subside from the repeated bout effect [69]. Therefore, resistancetrained individuals are less likely to experience extensive exercise-induced muscle damage [70]. However, AEL with dumbbells of $20 \%$ body mass during drop jumps increased creatine kinase and perceived muscle soreness, which peaked 24 hours after testing [71]. Creatine kinase responses were greater following higher drop jump volumes $(5 \times 6$ versus $5 \times 10$ ), which indicates the muscle damage response is subject to training volumes [71]. Greater muscle thickness occurred at 15 minutes and 24 hours post-exercise following AEL (120:80\% 1-RM) compared to traditional loading (80\%1-RM) for 6 sets of 5 bench press repetitions [72]. Yet, low volume (3 
Table 2. Acute performance implications of AEL, via weight releasers, in bench press and squat exercises

\begin{tabular}{|c|c|c|c|c|}
\hline Movement & $\begin{array}{l}\text { Training Status/ } \\
\text { Strength Level }\end{array}$ & $\begin{array}{l}\text { AEL Loading } \\
\text { Strategy }\end{array}$ & Load Magnitude & Performance Implications \\
\hline \multirow{6}{*}{$\begin{array}{l}\text { Bench } \\
\text { Press }\end{array}$} & $\begin{array}{c}\text { Recreationally } \\
\text { active men / Bench } \\
\text { 1-RM: 1.2-1.4xBM }\end{array}$ & $\begin{array}{l}2 \times 2 \text { reps } \\
\text { AEL on each } \\
\text { rep }\end{array}$ & $\begin{array}{c}\text { ECC: } 60-90 \% 1-R M \\
\text { CON: } 50 \% 1-R M\end{array}$ & $\begin{array}{c}\text { Best ECC load for AEL was } \\
\text { on average } 77.3 \% 1-R M \text {. ECC } \\
\text { loads to increase CON peak } \\
\text { power is individualized [20] }\end{array}$ \\
\hline & $\begin{array}{l}\text { Moderately trained } \\
\text { men }\end{array}$ & $\begin{array}{l}3 \times 1 \text { maximal } \\
\text { reps }\end{array}$ & $\begin{array}{l}\text { ECC: } 105 \% 1-\mathrm{RM} \\
\text { CON: } 100 \% 1-\mathrm{RM}\end{array}$ & $\begin{array}{c}\text { Increased concentric 1-RM } \\
{[16]}\end{array}$ \\
\hline & $\begin{array}{c}\text { Men and women } \\
\geq 1 \text {-year training } \\
\text { experience / Bench } \\
\text { 1-RM: 1.2x BM }\end{array}$ & $\begin{array}{l}1 \times 2 \text { reps at } \\
\text { each load } \\
A E L \text { on each } \\
\text { rep }\end{array}$ & $\begin{array}{l}\text { ECC: } 100 \% 1-\mathrm{RM} \\
\text { CON: } 30 \% 1-\mathrm{RM} \\
\text { ECC: } 100 \% 1-\mathrm{RM} \\
\text { CON: } 80 \% 1-\mathrm{RM}\end{array}$ & $\begin{array}{l}\text { Increased vertical force and } \\
\text { greater work [28] }\end{array}$ \\
\hline & $\begin{array}{c}\text { Men with 6-year } \\
\text { training experience } \\
\text { / Bench 1-RM: 1.3x } \\
\text { BM }\end{array}$ & $\begin{array}{c}3 \times 5 \text { reps } \\
\text { cluster sets } \\
\text { AEL on all reps } \\
3 \times 5 \text { reps } \\
\text { straight sets } \\
\text { AEL on first rep }\end{array}$ & $\begin{array}{l}\text { ECC: } 105 \% \\
\text { CON: } 80 \%\end{array}$ & $\begin{array}{l}\text { No improvement in concentric } \\
\text { action performance [62] }\end{array}$ \\
\hline & $\begin{array}{c}\text { Men and women } \\
\text { with } \geq 1 \text {-year train- } \\
\text { ing experience / } \\
\text { Bench 1-RM: } 1.0- \\
1.5 \times B M\end{array}$ & $\begin{array}{c}4 \times 5 \text { reps } \\
\text { AEL on first rep }\end{array}$ & $\begin{array}{c}\text { ECC: } 105 \% \\
\text { CON: } 50 \text { and } 65 \%\end{array}$ & $\begin{array}{c}\text { AEL rep } 1 \text { decreased velocity } \\
\text { No increase in CON velocity } \\
\text { Stronger subjects benefit } \\
\text { more } \\
\text { ECC velocity was faster on } \\
\text { reps 2-5 [30] }\end{array}$ \\
\hline & $\begin{array}{c}\text { Men } \geq 1 \text {-year train- } \\
\text { ing experience / } \\
\text { Bench 1-RM: } 1.5 x \\
\text { BM }\end{array}$ & $\begin{array}{l}1 \text { rep at each } \\
\text { CON load }\end{array}$ & $\begin{array}{c}\text { ECC: } 100 \text { and } \\
\text { 110\% 1-RM } \\
\text { CON: } 30,40,50,60 \\
70,80 \% 1-R M\end{array}$ & $\begin{array}{c}\text { AEL with 100\% 1-RM pro- } \\
\text { duced faster CON velocity } \\
\text { AEL with } 110 \% 1-\mathrm{RM} \text { altered } \\
\text { the change in velocity across } \\
\text { CON loads (30-80\% of 1RM) } \\
\text { Individual variations in barbell } \\
\text { displacement influenced AEL } \\
\text { effects [63] }\end{array}$ \\
\hline \multirow[t]{2}{*}{ Back Squat } & $\begin{array}{c}\text { Men with } \geq 1 \text {-year } \\
\text { training experience } \\
/ \\
\text { 1.8x BM squat }\end{array}$ & $\begin{array}{c}3 \times 5 \text { reps } \\
\text { cluster sets } \\
\text { AEL on all reps } \\
3 \times 5 \text { reps } \\
\text { straight sets } \\
\text { AEL on first rep }\end{array}$ & $\begin{array}{l}\text { ECC: } 105 \% \\
\text { CON: } 80 \%\end{array}$ & $\begin{array}{c}\text { AEL cluster sets: Increased } \\
\text { RFD, on reps } 3 \text { and } 5 . \\
\text { AEL straight sets: Increased } \\
\text { eccentric RFD stayed elevat- } \\
\text { ed until rep } 3 \\
{[32]}\end{array}$ \\
\hline & $\begin{array}{l}\text { Men } \geq 2 \text {-year train- } \\
\text { ing experience / } \\
\text { Squat 1-RM: 2x BM }\end{array}$ & $\begin{array}{c}3 \times 5 \text { reps } \\
\text { AEL on first rep } \\
3 \times 3 \text { reps } \\
\text { AEL on first rep }\end{array}$ & $\begin{array}{l}\text { ECC: } 120 \% \\
\text { CON: } 65 \% \\
\text { ECC: } 120 \% \\
\text { CON: } 80 \%\end{array}$ & $\begin{array}{c}\text { For CON 65\%, AEL increased } \\
\text { ECC and CON velocity and } \\
\text { power after rep } 1 . \\
\text { Rep } 1 \text { pacing strategies were } \\
\text { slower with AEL [19] }\end{array}$ \\
\hline $\begin{array}{l}\text { Front } \\
\text { Squat }\end{array}$ & $\begin{array}{c}\text { Men } \geq 1 \text {-year train- } \\
\text { ing experience / } \\
\text { Front squat 1-RM: } \\
131 \mathrm{~kg}\end{array}$ & $\begin{array}{c}2 \times 1 \text { rep per } \\
\text { load }\end{array}$ & $\begin{array}{c}\text { ECC: } 105,110 \\
\text { 120\% 1-RM } \\
\text { CON: } 90 \% 1-R M\end{array}$ & $\begin{array}{c}\text { Increased concentric power, } \\
\text { GRF, velocity. Greater im- } \\
\text { provements w/ heavier loads } \\
{[57]}\end{array}$ \\
\hline
\end{tabular}


total repetitions) AEL did not result in any additional post-exercise muscle swelling or soreness [61]. The lower volumes of AEL will likely not impose further muscle damage, but more research is necessary.

Still, there may be benefit to high volume AEL training, such as improved lactate clearing adaptations, as indicated by reductions in postexercise lactate compared to traditional loading in previously untrained [68] and trained men [73]. This is particularly important for athletic populations, as this may suggest that AEL could alter metabolically mediated muscular adaptations, such as strength, hypertrophy, or fatigue resistance. Achieving greater metabolic stress during resistance exercise has been shown to improve muscular strength and hypertrophy in men [74]. Further, altered lactate responses may drive important anabolic signaling pathways through increasing serum hormone levels of testosterone [75,76], cortisol [77], and growth hormone [78]. Resultantly, relatively high training volumes including AEL have shown greater postexercise testosterone elevations [73], while others have found AEL to result in similar concentrations of post-exercise total and bioavailable testosterone, cortisol, and growth hormone compared to traditional loading $[61,68,73,79]$. Although using supramaximal concentric loads during AEL may be taxing and induce an increased stress response, cortisol may be more susceptive to training volume than intensity [80]. As such, low volumes, such as one AEL (120\% $1-\mathrm{RM}$ ) repetition at the beginning of each of three back squat sets did not result in further cortisol responses [61]. However, the inclusion of multiple AEL repetitions across a session may compound and increase the overall training stress. None-theless, these acute responses may lead to strength, hypertrophy, or power adaptations.

The limited research implementing AEL during training interventions has shown promising results [18,81-83], but requires further exploration in explosive training adaptations, such as speed and power (Table 3). In untrained groups, AEL with an additional 50-60\% eccentric load during 1-6 weeks of isokinetic training has resulted in superior strength improvements compared to traditional methods $[18,83]$. However, untrained groups have noted similar strength gains following 10 weeks of AEL training with an additional $40 \%$ eccentric load [17]. Thus, in untrained populations, the efficacy of AEL for inducing superior strength gains is subject to the magnitude of the additional eccentric loading. However, these findings are based on interventions using computer driven apparatuses that may have limited applicability to human performance in sport or tactical settings. When resistance training with the bench press and squat, untrained men performed 3 sets of 6 AEL repetitions with increasing intensity across 5 weeks (eccentric loading, 100-121\% 1-RM; concentric loading, 40-49\% 1-RM) and experienced similar strength improvements as 4 sets of 6 repetitions with traditional loading (52.5-73\% 1-RM) [68]. Yet, rugby athletes trained with AEL using 4-5\% lower concentric loads and $18-25 \%$ higher eccentric loads than traditional loading, and experienced greater increases in back squat 1-RM after a 4 week AEL training block [81]. Overall, it seems the use of AEL may enable similar strength gains at lower training volumes, and strength improvement from AEL is greater when compared to concentric load matched traditional loading $[15,17,21]$. Collectively, strength improvement from AEL may be attributed primarily to neural adaptations (e.g., type II fiber recruitment) [84], which may occur more rapidly during AEL for untrained individuals. Presumably, the $A E L$ intervention that elicits further neuromuscular adaptations may elicit improvements in strength.

Although limited research exists in relation to chronic $A E L$ effects on power, AEL training has shown improvements in countermovement jump height [25] and reactive strength index [81]. This may be an indirect result of greater stretch shortening cycle reflex adaptations due to training consistently at increased eccentric velocities [85]. In athletic populations, eccentric overloading (1.9 times the concentric load) for 6 sets of 8-RM resulted in greater explosive capabilities as indicated by higher jump performances and greater type II muscle phenotype expressions after 6 weeks of training [14]. High performance volleyball players experienced greater increases in countermovement jump height, velocity, and power after 5 weeks of training using AEL with $40 \mathrm{~kg}$ and $20 \mathrm{~kg}$ of additional eccentric load for men and women, respectively [25]. Greater ability to utilize the stretch-shortening cycle has also been demonstrated in fast AEL protocols compared to traditional loading with rugby athletes, who experienced small increases in reactive strength index following 4 weeks of training with Smith machine back squat sessions and power sessions with plyometrics [81]. However, the same athletes experienced slower sprinting ability from training with the fast AEL protocol, but improved sprinting times following the slow tempo AEL protocol [81]. Thus, more research is necessary as fast eccentric training protocols have been shown to be superior to slow eccentric methods for improving strength and power adaptations [86]. In summary, the exercise 
Table 3. Chronic performance implications from accentuated eccentric loading in men.

\begin{tabular}{|c|c|c|c|c|c|c|}
\hline $\begin{array}{c}\text { Move- } \\
\text { ment }\end{array}$ & $\begin{array}{l}\text { Loading } \\
\text { Method }\end{array}$ & $\begin{array}{l}\text { Training Sta- } \\
\text { tus/ Strength }\end{array}$ & $\begin{array}{l}\text { Training } \\
\text { Duration }\end{array}$ & $\begin{array}{c}\text { AEL Loading } \\
\text { Strategy }\end{array}$ & Load Magnitude & $\begin{array}{l}\text { Performance } \\
\text { Implications }\end{array}$ \\
\hline \multirow[t]{2}{*}{$\begin{array}{l}\text { Drop } \\
\text { Jumps }\end{array}$} & Dumbbells & $\begin{array}{l}\geq 2 \text { years } \\
\text { Strength } \\
\text { trained }\end{array}$ & 3 weeks & $\begin{array}{c}5 \times 6 \text { (session } \\
\text { 1) AEL on all } \\
\text { reps } \\
\\
5 \times 10 \text { (session } \\
2 \text { ) } \\
\text { AEL on all reps }\end{array}$ & $\begin{array}{l}\text { ECC: } 20 \% \text { BM } \\
\text { CON: BM }\end{array}$ & $\begin{array}{l}\text { Improved jump } \\
\text { height, CON } \\
\text { strength, protec- } \\
\text { tion against mus- } \\
\text { cle damage [71] }\end{array}$ \\
\hline & Dumbbells & $\begin{array}{c}1.65 \times \mathrm{BM} \\
\text { squat } \\
\text { Strength- } \\
\text { trained } \\
\text { Academy rug- } \\
\text { by players }\end{array}$ & 4 weeks & Not listed & $\begin{array}{c}\text { ECC: } 20 \% \text { BM } \\
\text { CON: BM }\end{array}$ & $\begin{array}{l}\text { Increased peak } \\
\text { force \& jump } \\
\text { height, decreased } \\
\text { time in sprint and } \\
\text { COD [87] }\end{array}$ \\
\hline $\begin{array}{l}\text { Counter- } \\
\text { movement } \\
\text { Jumps }\end{array}$ & Dumbbells & $\begin{array}{c}\geq 2 \text { years } \\
\text { Elite volleyball } \\
\text { players }\end{array}$ & 5 weeks & $\begin{array}{c}2 \times 5 \\
\text { AEL on all reps }\end{array}$ & $\begin{array}{c}\text { Men } \\
\text { ECC: } 40 \mathrm{~kg} \text { CON: } \\
\text { BM } \\
\text { Women } \\
\text { ECC: } 20 \mathrm{~kg} \text { CON: } \\
\text { BM }\end{array}$ & $\begin{array}{l}\text { Increased jump } \\
\text { height, velocity, } \\
\text { power [25] }\end{array}$ \\
\hline $\begin{array}{l}\text { Bench } \\
\text { Press }\end{array}$ & $\begin{array}{l}\text { Weight releas- } \\
\text { ers }\end{array}$ & $\begin{array}{l}\text { Untrained } \\
\text { Physically } \\
\text { active }\end{array}$ & 5 weeks & $\begin{array}{c}3 \times 6 \\
A E L \text { on all reps }\end{array}$ & $\begin{array}{c}\text { ECC: } 100 \% 1-\mathrm{RM} \\
\text { CON: } 40 \%\end{array}$ & $\begin{array}{c}\text { Increased 1-RM } \\
\text { bench press and } \\
\text { squat [68] }\end{array}$ \\
\hline \multirow[t]{2}{*}{ Squat } & $\begin{array}{c}\text { Weight releas- } \\
\text { ers }\end{array}$ & $\begin{array}{c}\text { Resistance } \\
\text { trained } \\
\text { 1.7x BM squat } \\
\text { Academy rug- } \\
\text { by players }\end{array}$ & $\begin{array}{c}4 \text { weeks } \\
+ \\
4 \text { weeks } \\
\text { (8 total) }\end{array}$ & $\begin{array}{c}2-3 \times 6-8 \\
A E L \text { on all reps } \\
2-5 \times 4-5 \\
A E L \text { on all reps }\end{array}$ & $\begin{array}{c}\text { ECC: } 92-98 \% \\
\text { CON: } 68-72 \\
\text { 1-RM } \\
\text { ECC: } 106-110 \% \\
\text { CON: } 77-81 \% \\
\text { 1-RM }\end{array}$ & $\begin{array}{l}\text { Increased } \\
\text { strength, velocity, } \\
\text { sprint speed, and } \\
\text { reactive strength } \\
\text { index [81] }\end{array}$ \\
\hline & $\begin{array}{l}\text { Weight releas- } \\
\text { ers }\end{array}$ & $\begin{array}{l}\geq 1 \text { year } \\
\geq \text { BM squat } \\
\text { Resistance } \\
\quad \text { trained }\end{array}$ & 5 weeks & $\begin{array}{c}4 \times 5 \\
3 \times 4 \\
3 \times 2 \\
\\
\text { AEL on all reps }\end{array}$ & $\begin{array}{c}\text { ECC: } 105-115 \% \\
\text { CON: } 55-65 \% \\
1-R M\end{array}$ & $\begin{array}{l}\text { ncreased in ec- } \\
\text { centric 1-RM, CMJ } \\
\text { height [88] }\end{array}$ \\
\hline \multirow[t]{2}{*}{ Leg Press } & $\begin{array}{l}\text { Weight releas- } \\
\text { ers }\end{array}$ & $\begin{array}{c}\geq 2 \text { years } \\
1.7 \times \text { BM 10- } \\
\text { RM leg press } \\
\text { Healthy men }\end{array}$ & 10 weeks & $\begin{array}{c}3 \times 10-R M \\
\text { AEL on all reps }\end{array}$ & $\begin{array}{l}\text { ECC: Concentric } \\
\quad+40 \% 1-\mathrm{RM} \\
\text { CON: concentric }\end{array}$ & $\begin{array}{l}\text { No strength im- } \\
\text { provements [73] }\end{array}$ \\
\hline & $\begin{array}{l}\text { Weight releas- } \\
\text { ers }\end{array}$ & $\begin{array}{l}\geq 2 \text { years } \\
\text { Healthy men }\end{array}$ & 10 weeks & $\begin{array}{c}\text { AEL on all reps } \\
3 \times 6 \text { (session } \\
1 \text { ) } \\
3 \times 10 \text { (session } \\
2 \text { ) }\end{array}$ & $\begin{array}{c}\text { ECC: Concentric } \\
+40 \% \\
\text { CON: concentric }\end{array}$ & $\begin{array}{l}\text { Increased peak } \\
\text { torque and 1-RM } \\
\text { strength [21] }\end{array}$ \\
\hline $\begin{array}{l}\text { Elbow } \\
\text { extension } \\
\text { flexion }\end{array}$ & Free weights & $\begin{array}{l}\geq 1 \text { year } \\
\text { BM bench }\end{array}$ & 9 weeks & $\begin{array}{c}3 \times 10 \\
\text { AEL on all reps }\end{array}$ & $\begin{array}{c}\text { ECC: } 110-120 \% \\
1-R M \\
\text { CON: } 75 \% 1-R M\end{array}$ & $\begin{array}{c}\text { Increased CON } \\
\text { elbow flexor and } \\
\text { extensor strength } \\
{[15]}\end{array}$ \\
\hline
\end{tabular}

BM, body mass; ECC, eccentric action; CON, concentric action; COD, change of direction; 1-RM, one-repetition maximum; CMJ, countermovement jump; 10-RM, ten-repetition maximum

* Results from computer-driven apparatuses are not displayed in this table. Instead this is limited to research highlighting more practical and readily available methods manual weight releasing or affordable weight releaser devices on free weight exercises. 
used, tempo of the movement's eccentric action, and loading strategies must be taken into consideration, as they may have different implications for the necessary prescription of AEL.

\section{LOADING STRATEGIES FOR IMPLEMENTING ACCENTUATED ECCENTRIC LOADING}

The stimulus of AEL is also dependent upon the magnitudeofeccentricloading, whichisgenerally broken down into submaximal or supramaximal loads. In submaximal AEL exercise, an eccentric load greater than the concentric load, but not exceeding the concentric 1-RM is implemented. As previously mentioned, AEL with submaximal loading has enhanced jumping and throwing performance $[20,27]$. Interestingly, a wide range of submaximal eccentric loads during AEL may yield positive results for exercises performed with explosive intent. Yet, the magnitude of submaximal eccentric load used to elicit a positive performance enhancement from AEL depends upon the exercise: drop jump (20-30\% of body mass), countermovement jump (20$40 \mathrm{~kg}$ ), bench press throw $(60-80 \mathrm{~kg})$, bench press (77-120\% 1-RM). Further, the eccentric load that improves power the most may be dependent upon the individual [20]. However, some have reported no improvement in drop jump performances from AEL [22]. Considering the naturally high rate of muscle lengthening and required skill during drop jumps, landing at a faster rate due to the eccentric overload may have resulted in the inability to respond to AEL in a mechanically effective and efficient manner. Therefore, it may be possible that the effects of AEL on explosive concentric performances are dependent upon creating greater neural drive than traditional loading methods would achieve, which will not occur if movement mechanics are interrupted.

There are many ways to implement AEL, such as manualapplication offorcesbyanotherindividual, elastic bands, computer-driven apparatuses, and weight releasing (manually released by the participant or a device) $[8,89,90]$. The manual application of forces may be useful but creates difficulty when prescribing quantifiable loads, as the amount of resistance provided may differ between individuals and between repetitions by the same individual. Computer-driven methods appear to be effective [82,91], but the cost of purchasing and implementing them are not viable for most practitioners. Other methods of implementing low magnitudes of submaximal AEL that are more quantifiable are elastic bands or dumbbells, which are held during the eccentric actions and released prior to initiating

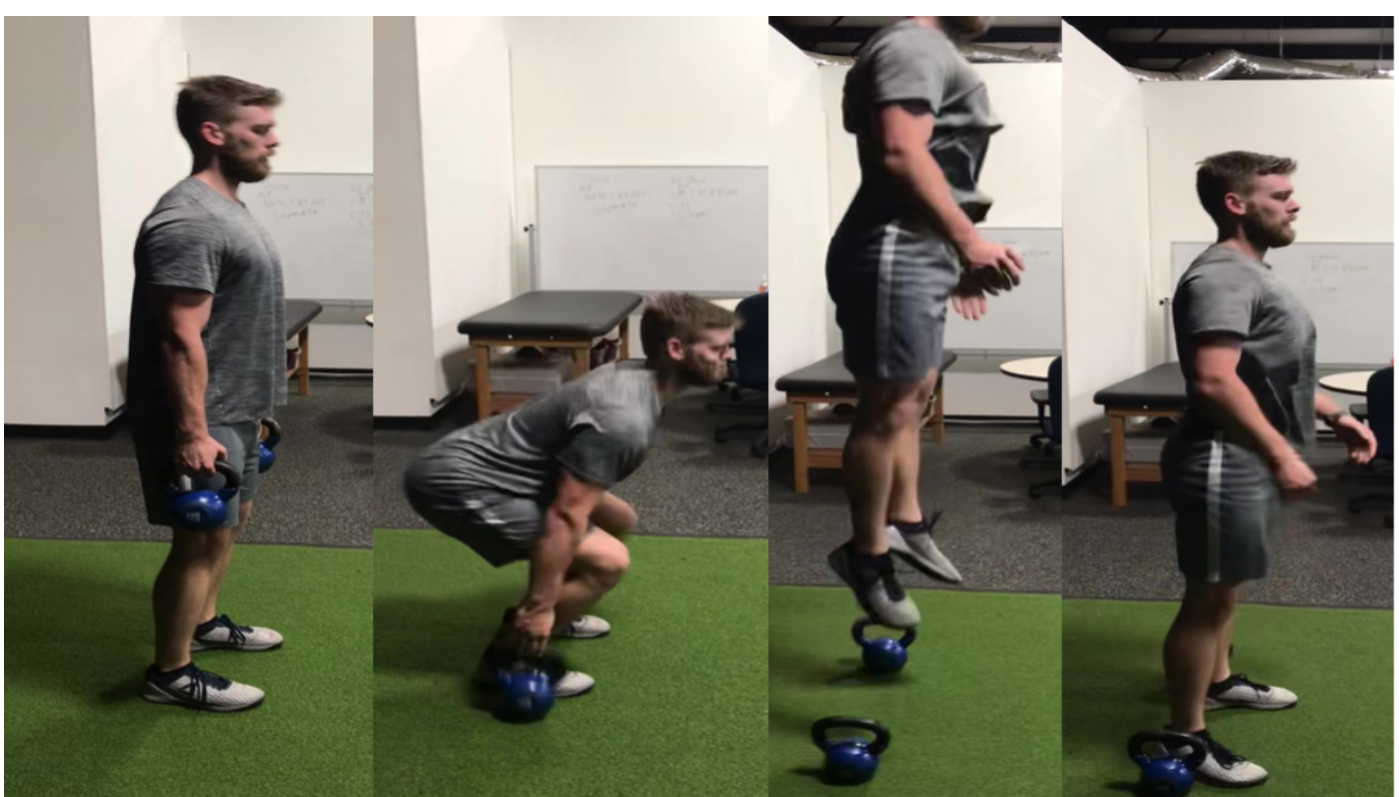

Figure 2. Example depiction of manually releasing additional eccentric loads to implement accentuated eccentric loading during jumping variations. 


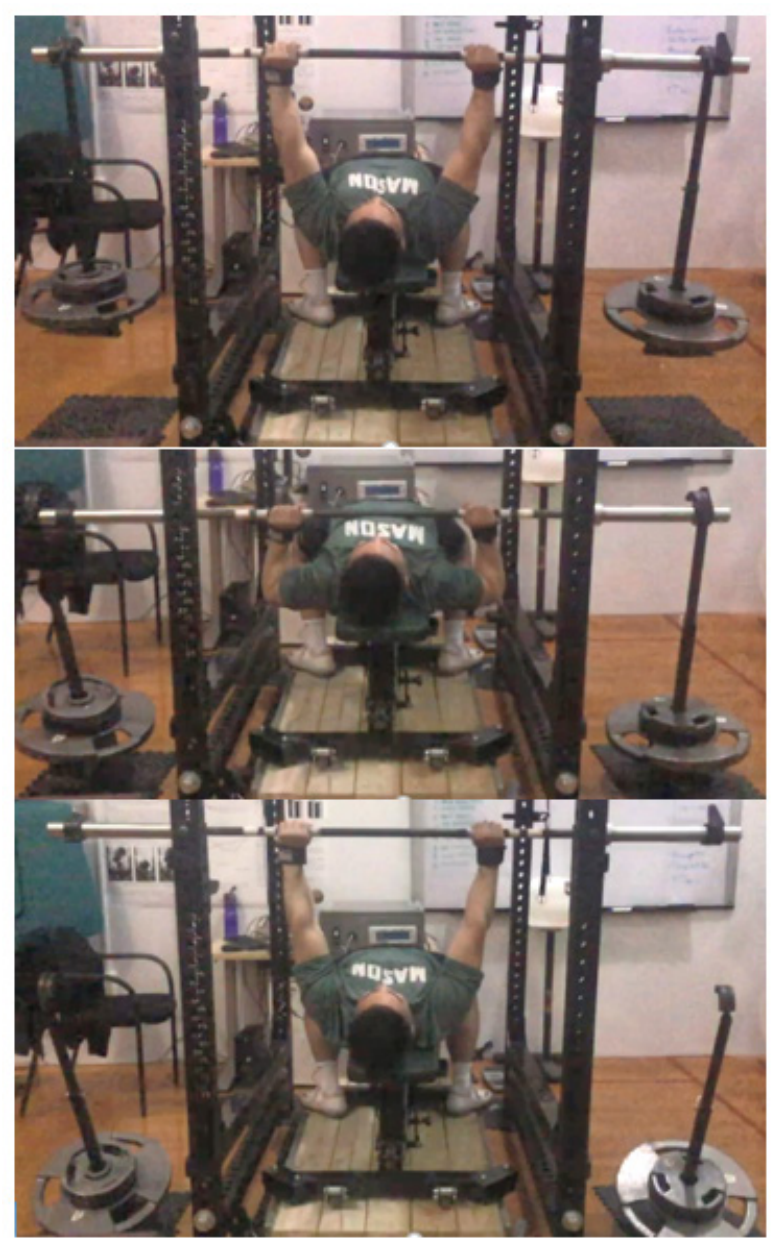

Figure 3. Example depiction of weight releasers to implement accentuated eccentric loading during the bench press, which would be similar for squatting movements.

concentric actions (Figure 2)[22-24,26]. These are suitable for explosive movements, such as countermovement jumps, drop jumps, and bench press throws, but weight releaser devices are more useful for movements such as the bench press and squat that involve greater concentric loads. The weight releaser devices use hooks that automatically disengage upon impact with the ground, which does not require the individual to release the weight (Figure 3) $[19,29,30,32]$. Further, it is necessary to ensure the weight releasers are set to a standardized height that allows them to disengage immediately prior to the barbell touching the chest during the bench press or the individual reaching their lowest attainable squat depth.

Implementing AEL during the squat and the bench press exercises is often conducted using additional eccentric loads either at or above the concentric 1-RM via weight releaser devices $[8,16,19,20,30,32,57,61]$. Following the first eccentric movement, the weight releasers disengage upon ground contact, and the concentric action is performed with the remaining load. Although previously thought to have minimal influence, weight releasers can alter movement mechanics such as bar path and speed of the eccentric action $[28,30]$. Further, the heavier eccentric loads may force the individual to adopt a slower pacing strategy in order to control the weight releasers while descending, which has led to decreased performances on repetitions where AEL is implemented [19,30]. However, recent research has shown it is unnecessary to reattach the weight releasers after the first repetition; a single AEL repetition in the bench press and squat can increase performance compared to traditional loading on up to 5 subsequent repetitions within the set [19,30,32]. This reduces the overall intensity, compared to AEL on all repetitions, while maintaining the potentiating effect on concentric performance. Another concern is that weight releasers can alter movement mechanics $[28,30]$ and force the individual to adopt slower pacing strategies 
to handle the supramaximal loads $[19,30]$, which can lead to decreased concentric performance. To account for these variations in pacing strategies, eccentric tempo has been controlled for (ex. 3 second eccentric tempo) to increase performances [57]. However, if eccentric velocities are too low, AEL can lose its potentiating effect, making traditional loading performance better $[19,30]$. When implementing supramaximal AEL, if eccentric tempo is too slow or the load cannot be properly lowered, the eccentric load should be reduced.

It has been suggested that fatigue from supramaximal AEL with 105-120\% 1-RM may reduce concentric 1-RM performances [92]. Yet, supramaximal AEL may be better suited for the provocation of chronic adaptations, as they are potentially too taxing for acute potentiation purposes. Further, when training sessions were intended to produce faster, more powerful, repetitions with submaximal concentric loading from 30-80\% 1-RM, AEL with 105-120\% resulted in either similar or lower concentric velocities and power compared to traditional loading in both squat and bench press exercises [19,2830,32]. Yet, investigation of multiple repetitions performed following an initial $\mathrm{AEL}$ repetition has shown faster eccentric actions followed by either similar or enhanced concentric velocity and power $[19,30,32,60]$. Thus, the combination of fatigue and altered mechanics may result in an inferior concentric performance within the same repetition as the AEL, but when subsequent repetitions are performed within the same set of an AEL repetition the fatigue may subside revealing potentiating effects of the latter repetitions. Although AEL effects appear to be dependent upon the concentric and eccentric loading $[19,20]$, more research is necessary to understand the appropriate magnitudes of concentric and eccentric loads, as well as the ratio between the two. Nonetheless, the aforementioned findings suggest that practitioners do not need to reload the weight releasers after every repetition, but instead can have their athletes perform multiple repetitions following an initial AEL repetition to reap the potentiating effects of AEL.

In addition to understanding general mechanisms and magnitudes for loading parameters for $A E L$, understanding the population intended to use AEL is necessary. Typically, post-activation performance enhancement occurs at faster rates and higher magnitudes for individuals who have greater baseline strength levels [93,94]. Therefore, stronger individuals are more likely to experience performance enhancement from AEL, although more research is necessary to support these findings [30]. Nonetheless, the stronger individuals are more likely to successfully manage the heavier and more rapid movement patterns. Thus, some AEL methods may be better suited for relatively stronger individuals but should not be completely discarded for relatively weaker individuals, as a multifaceted approach to implementing AEL is recommended. It is likely that the eccentric loading magnitudes will differ based upon strength levels, with stronger individuals requiring greater eccentric overloads [27]. For example, men may require heavier eccentric loading than women to elicit potentiation from AEL [25]. Thus, when prescribing the eccentric load during $A E L$, it is important to consider training experience, gender, and relative strength.

\section{PRACTICAL APPLICATIONS}

Acute and chronic performance improvements (i.e., speed and power adaptations) have been demonstrated using AEL in several exercises. This is made possible through various unique neural, molecular, and metabolic responses to eccentric overloading. The most popular methods for implementing submaximal AEL are jumping variants (e.g., drop jumps, countermovement jumps, squat jumps) and bench press throws. Elastic bands (20$30 \%$ of body mass) and dumbbells/kettlebells (20\% body mass) have been shown to increase jump height performance. Maximal and supramaximal AEL are best suited for multi-joint exercises involving large muscle mass, such as the back squat and bench press, while using computer-driven devices or weight releasers. It is recommended the eccentric load be heavier than the concentric 1-RM (105$120 \%$ ), but load selection may depend upon the experience of the lifter (Figure 4), as the untrained may adopt a slower pacing strategy reducing the benefits associated with faster eccentric velocities or loads. Due to the negative factors of fatigue, use of supramaximal AEL on the first repetition of a set followed by non-AEL repetitions to finish the set have been investigated. Results indicate that weight releasers do not need to be used on every repetition in order to provide benefits to concentric performance, as the fatigue from the AEL repetition likely subsides to allow the potentiating effects of the heavier loads to occur during the latter repetitions. Therefore, it may be concluded that AEL on the first repetition of each set may allow for higher intensity eccentric actions with similar recovery patterns to traditional loading. 
Accentuated eccentric loading (AEL) for

concentric velocity and power improvements

\begin{tabular}{|c|c|c|c|c|c|c|c|c|}
\hline \multirow{3}{*}{$\begin{array}{l}\text { Less } \\
\text { Training } \\
\text { Experience } \\
\text { and AEL } \\
\text { Familiarity }\end{array}$} & \multicolumn{2}{|c|}{ Submaximal AEL } & \multicolumn{2}{|c|}{ Submaximal AEL } & \multicolumn{2}{|c|}{ Maximal AEL } & \multicolumn{2}{|c|}{ Supramaximal AEL } \\
\hline & $\begin{array}{l}\text { Eccentric } \\
\text { Loads }\end{array}$ & $\begin{array}{l}\text { Concentric } \\
\text { Loads }\end{array}$ & $\begin{array}{l}\text { Eccentric } \\
\text { Loads }\end{array}$ & $\begin{array}{l}\text { Concentric } \\
\text { Loads }\end{array}$ & $\begin{array}{l}\text { Eccentric } \\
\text { Loads }\end{array}$ & $\begin{array}{l}\text { Concentric } \\
\text { Loads }\end{array}$ & $\begin{array}{l}\text { Eccentric } \\
\text { Loads }\end{array}$ & $\begin{array}{l}\text { Concentric } \\
\text { Loads }\end{array}$ \\
\hline & $\begin{array}{c}20 \% \mathrm{BM} \\
\downarrow \\
30 \% \mathrm{BM}\end{array}$ & BM & $\begin{array}{c}60 \% \\
\downarrow \\
90 \%\end{array}$ & $\begin{array}{c}30 \% \\
\downarrow \\
50 \%\end{array}$ & $100 \%$ & $\begin{array}{c}30 \% \\
\downarrow \\
80 \%\end{array}$ & $\stackrel{105 \%}{\downarrow}$ & $\begin{array}{c}30 \% \\
\downarrow \\
90 \%\end{array}$ \\
\hline $\begin{array}{l}\text { Training } \\
\text { Experience } \\
\text { and AEL } \\
\text { Familiarity }\end{array}$ & \multicolumn{2}{|c|}{$\begin{array}{l}\text { Dumbbells, bands, } \\
\text { kettlebells: } \\
\text { Countermovement, } \\
\text { Drop, Depth Jumps }\end{array}$} & \multicolumn{2}{|c|}{$\begin{array}{c}\text { Weight Releasers: } \\
\text { Bench Throws } \\
\text { Back squat } \\
\text { Front Squat } \\
\text { Bench Press }\end{array}$} & \multicolumn{2}{|c|}{$\begin{array}{c}\text { Weight Releasers: } \\
\text { Back squat } \\
\text { Front Squat } \\
\text { Bench Press }\end{array}$} & \multicolumn{2}{|c|}{$\begin{array}{c}\text { Weight Releasers: } \\
\text { Back squat } \\
\text { Front Squat } \\
\text { Bench Press }\end{array}$} \\
\hline & \multicolumn{4}{|c|}{$\begin{array}{l}\text { Relatively Weaker } \\
<1.5 \text { Bench press }\end{array}$} & \multicolumn{4}{|c|}{$\begin{array}{c}\text { Relatively Stronger } \\
>1.5 \text { Bench Press } \\
>2.0 \text { Back squat }\end{array}$} \\
\hline
\end{tabular}

Figure 4. Recommendations for loading strategies when implementing AEL according to current findings.

Although subject to the concentric and eccentric loads used, eccentric velocity, and exercise selected, AEL may enable greater velocities and power output to be attained during concentric actions. Therefore, practitioners may prescribe these methods to increase eccentric intensity and improve concentric performances without the need for extended recovery periods. To increase the likelihood of positive performance responses and reduce the risk of muscle damage when implementing AEL programming, it is recommended the training experience and relative strength of each individual be considered. Decisions may simply be made from the viewpoint of the practitioner in terms of affordability, difficulty, and applicability of the device used to implement AEL. Therefore, continuous efforts are needed to study which loading strategies may be most beneficial regarding each specific AEL method. However, it is likely that the strength of the individual may dictate the type of AEL, exercise, and magnitude of eccentric overload used in training (Figure 4).

\section{REFERENCES}

1. Hollander DB, Kraemer RR, Kilpatrick MW, Ramadan ZG, Reeves GV, Francois M, et al. Maximal eccentric and concentric strength discrepancies between young men and women for dynamic resistance exercise. J Strength Cond Res 2007;21:34-40. https:// doi.org/10.1519/R-18725.1.
2. Katz B. The relation between force and speed in muscular contraction. J Physiol 1939;96:45-64. https://doi.org/10.1113/jphysiol.1939.sp003756.

3. Westing SH, Seger JY, Karlson E, Ekblom B. Eccentric and concentric torque-velocity characteristics of the quadriceps femoris in man. Eur $\mathrm{J}$ Appl Physiol 1988;58:100-4

4. Henneman E, Somjen G, Carpenter DO. Excitability and Inhibility of Motoneurons of Different Sizes. J Neurophysiol 1965;28:599-620. https://doi. org/10.1152/jn. 1965.28.3.599.

5. Hunter SK, Duchateau J, Enoka RM. Muscle fatigue and the mechanisms of task failure: Exerc Sport Sci Rev 2004;32:44-9. https://doi.org/10.1097/00003677200404000-00002.

6. Mendell LM. The size principle: a rule describing the recruitment of motoneurons. I Neurophysiol 2005;93:3024-6. classicessays.00025.2005.

7. Tøien T, Pedersen Haglo H, Unhjem R, Hoff J, Wang E. Maximal strength training: the impact of eccentric overload. J Neurophysiol 2018;120:2868-76. https:// doi.org/10.1152/jn.00609.2018.

8. Wagle JP, Taber CB, Cunanan AJ, Bingham GE, Carroll KM, DeWeese $\mathrm{BH}$, et al. Accentuated Eccentric Loading for Training and Performance: A Review. Sports Med 2017. https://doi.org/10.1007/ s40279-017-0755-6.

9. Nardone A, Romanò C, Schieppati M. Selective recruitment of high-threshold human motor units during voluntary isotonic lengthening of active muscles. J Physiol 1989;409:451-71. https://doi. org/10.1113/jphysiol.1989.sp017507.

10. Komi PV. Physiological and Biomechanical Correlates of Muscle Function: Effects of Muscle Structure and 
Stretch-Shortening Cycle on Force and Speed. Exerc Sport Sci Rev 1984;12:81-122.

11. Rack PMH, Westbury DR. The short range stiffness of active mammalian muscle and its effect on mechanical properties. J Physiol 1974;240:331-50. https://doi.org/10.1113/jphysiol.1974.sp010613.

12. Cormie $P$, McGuigan M, Newton RU. Changes in the eccentric phase contribute to improved stretchshorten cycle performance after training. Med Sci Sports Exerc 2010;42:1731-44. https://doi. org/10.1249/MSS.0b013e3181d392e8.

13. Friedmann B, Kinscherf $R$, Vorwald $S$, Müller $H$, Kucera K, Borisch S, et al. Muscular adaptations to computer-guided strength training with eccentric overload. Acta Physiol Scand 2004;182:77-88. https://doi.org/10.1111/j.1365-201X.2004.01337.x.

14. Friedmann-Bette B, Bauer T, Kinscherf R, Vorwald S, Klute K, Bischoff D, et al. Effects of strength training with eccentric overload on muscle adaptation in male athletes. Eur J Appl Physiol 2010;108:821-36. https:// doi.org/10.1007/s00421-009-1292-2.

15. The effects of accentuated eccentric loading on strength, muscle hypertrophy, and neural adaptations in trained individuals. The Journal of Strength \& Conditioning Research. 2002; 16(1):25-32.

16. Doan BK, Newton RU, Marsit JL, RIPLETT-McBRIDE NT, Koziris LP, Fry AC, et al. Effects of Increased Eccentric Loading On Bench Press 1RM. J Strength Cond Res 2002;16:9. https://doi.org/10.1519/15334287(2002)016<0009:EOIELO>2.0.CO;2.

17. Godard MP, Wygand JW, Carpinelli RN, Catalano S, Otto RM. Effects of Accentuated Eccentric Resistance Training on Concentric Knee Extensor Strength. J Strength Cond Res 1998;12:26-9.

18. Kaminski TW, Wabbersen CV, Murphy RM. Concentric Versus Enhanced Eccentric Hamstring Strength Training: Clinical Implications. J Athl Train 1998;33:216-21

19. Merrigan JJ, Tufano JJ, Falzone M, Jones MT. Effectiveness of Accentuated Eccentric Loading: Contingent on Concentric Load. Int J Sports Physiol Perform 2020;16:66-72. https://doi.org/10.1123/ ijspp.2019-0769.

20. Ojasto T, Häkkinen K. Effects of different accentuated eccentric load levels in eccentric-concentric actions on acute neuromuscular, maximal force, and power responses. J Strength Cond Res 2009;23:996-1004.

21. Walker S, Blazevich AJ, Haff GG, Tufano JJ, Newton RU, Häkkinen K. Greater Strength Gains after Training with Accentuated Eccentric than Traditional Isoinertial Loads in Already Strength-Trained Men. Front Physiol 2016;7. https://doi.org/10.3389/fphys.2016.00149.

22. Aboodarda SJ, Byrne JM, Samson M, Wilson BD, Mokhtar AH, Behm DG. Does Performing Drop Jumps With Additional Eccentric Loading Improve Jump Performance? J Strength Cond Res 2014;28:231423. https://doi.org/10.1519/JSC.0000000000000498.

23. Aboodarda SJ, Yusof A, Osman NAA, Thompson MW, Mokhtar AH. Enhanced Performance With Elastic Resistance During the Eccentric Phase of a
Countermovement Jump. Int J Sports Physiol Perform 2013;8:181-7. https://doi.org/10.1123/ijspp.8.2.181.

24. Bridgeman LA, McGuigan MR, Gill ND, Dulson DK. The Effects of Accentuated Eccentric Loading on the Drop Jump Exercise and the Subsequent Postactivation Potentiation Response: J Strength Cond Res 2017;31:1620-6. https://doi.org/10.1519/ JSC. 0000000000001630 .

25. Sheppard J, Hobson S, Barker M, Taylor K, Chapman D, McGuigan M, et al. The Effect of Training with Accentuated Eccentric Load Counter-Movement Jumps on Strength and Power Characteristics of High-Performance Volleyball Players. Int J Sports Sci Coach 2008;3:355-63. https://doi. org/10.1260/174795408786238498.

26. Sheppard J, Newton R, McGuigan M. The Effect of Accentuated Eccentric Load on Jump Kinetics in High-Performance Volleyball Players. Int $\mathrm{J}$ Sports Sci Coach 2007;2:267-73. https://doi. org/10.1260/174795407782233209.

27. Sheppard JM, Young K. Using Additional Eccentric Loads to Increase Concentric Performance in the Bench Throw: J Strength Cond Res 2010;24:2853-6. https://doi.org/10.1519/JSC.0b013e3181e2731b.

28. Castro AH, Zangakis D, Moir GL. The effects of accentuated eccentric loading on mechanical variables and agonist electromyography during the bench press. Sports 2020;8:79.

29. Lates AD, Greer BK, Wagle JP, Taber CB. Accentuated Eccentric Loading and Cluster Set Configurations in the Bench Press. J Strength Cond Res 2020;Publish Ahead of Print. https://doi. org/10.1519/JSC.0000000000003664.

30. Merrigan JJ, Tufano JJ, Jones MT. Potentiating Effects of Accentuated Eccentric Loading are Dependent upon Relative Strength. J Strength Cond Res 2021;35(5):1208-1216. doi: 10.1519/ JSC. 0000000000004010

31. Moore CA, Weiss LW, Schilling BK, Fry AC, Li Y. Acute effects of augmented eccentric loading on jump squat performance. J Strength Cond Res 2007;21:372.

32. Wagle J, Taber C, Carroll K, Cunanan A, Sams M, Wetmore A, et al. Repetition-to-Repetition Differences Using Cluster and Accentuated Eccentric Loading in the Back Squat. Sports 2018;6:59. https://doi. org/10.3390/sports6030059.

33. Aagaard P, Simonsen EB, Andersen JL, Magnusson SP, Halkjær-Kristensen J, Dyhre-Poulsen P. Neural inhibition during maximal eccentric and concentric quadriceps contraction: effects of resistance training. J Appl Physiol 2000;89:2249-57. https://doi. org/10.1152/jappl.2000.89.6.2249.

34. Enoka RM. Eccentric contractions require unique activation strategies by the nervous system. J Appl Physiol 1996;81:2339-46. https://doi.org/10.1152/ jappl.1996.81.6.2339.

35. Kellis E, Arambatzi F, Papadopoulos C. Effects of load on ground reaction force and lower limb kinematics during concentric squats. J Sports Sci 2005;23:104555. https://doi.org/10.1080/02640410400022094. 
36. Pasquet B, Carpentier A, Duchateau J, Hainaut K. Muscle fatigue during concentric and eccentric contractions. Muscle Nerve 2000;23:1727-35. https://doi.org/10.1002/10974598(200011)23:11<1727::AID-MUS9>3.0.CO;2-Y.

37. Duchateau J, Enoka RM. Neural control of lengthening contractions. J Exp Biol 2016;219:197-204. https:// doi.org/10.1242/jeb.123158

38. Pasquet B, Carpentier A, Duchateau J. Specific modulation of motor unit discharge for a similar change in fascicle length during shortening and lengthening contractions in humans. J Physiol 2006;577:753-65. https://doi.org/10.1113/jphysiol.2006.117986.

39. Søgaard K, Christensen H, Jensen BR, Finsen L, Sjøgaard G. Motor control and kinetics during low level concentric and eccentric contractions in man. Electroencephalogr Clin Neurophysiol 1996;101:45360.

40. Sarto F, Franchi MV, Rigon PA, Grigoletto D, Zoffoli $\mathrm{L}$, Zanuso S, et al. Muscle activation during leg-press exercise with or without eccentric overload. Eur J Appl Physiol 2020. 120(7), 1651-1656.

41. Amiridis IG, Martin A, Morlon B, Martin L, Cometti G, Pousson $\mathrm{M}$, et al. Co-activation and tension-regulating phenomena during isokinetic knee extension in sedentary and highly skilled humans. Eur J Appl Physiol 1996;73:149-56. https://doi.org/10.1007/ BF00262824.

42. Kulig K, Powers CM, Shellock FG, Terk M. The effects of eccentric velocity on activation of elbow flexors: evaluation by magnetic resonance imaging. Med Sci Sports Exerc 2001;33:196-200.

43. Nardone A, Schieppati M. Shift of activity from slow to fast muscle during voluntary lengthening contractions of the triceps surae muscles in humans. J Physiol 1988;395:363-81. https://doi.org/10.1113/ jphysiol.1988.sp016924.

44. Del Valle A, Thomas CK. Firing rates of motor units during strong dynamic contractions. Muscle Nerve 2005;32:316-25. https://doi.org/10.1002/mus.20371.

45. Douglas J, Pearson S, Ross A, McGuigan M. Eccentric Exercise: Physiological Characteristics and Acute Responses. Sports Med 2017;47:663-75. https://doi. org/10.1007/s40279-016-0624-8

46. Abbruzzese G, Morena M, Spadavecchia L, Schieppati M. Response of arm flexor muscles to magnetic and electrical brain stimulation during shortening and lengthening tasks in man. J Physiol 1994;481:499507. https://doi.org/10.1113/jphysiol.1994.sp020458.

47. Duchateau J, Baudry S. Insights into the neural control of eccentric contractions. J Appl Physiol 2014; 116:1418-25. japplphysiol.00002.2013.

48. Linari M, Lucii L, Reconditi M, Casoni ME, Amenitsch $\mathrm{H}$, Bernstorff $\mathrm{S}$, et al. A combined mechanical and $X$-ray diffraction study of stretch potentiation in single frog muscle fibres. J Physiol 2000;526 Pt 3:589-96. https://doi.org/10.1111/j.1469-7793.2000.00589.x.

49. Herzog $W$. The role of titin in eccentric muscle contraction. J Exp Biol 2014;217:2825-33. https://doi. org/10.1242/jeb.099127.

50. Herzog JA, Leonard TR, Jinha A, Herzog W. Are titin properties reflected in single myofibrils? J Biomech 2012;45:1893-9. https://doi.org/10.1016/j. jbiomech.2012.05.021

51. Herzog W, Leonard TR, Joumaa V, Mehta A. Mysteries of Muscle Contraction. J Appl Biomech 2008;24:113. https://doi.org/10.1123/jab.24.1.1

52. Herzog W, Powers K, Johnston K, Duvall M. A new paradigm for muscle contraction. Front Physiol 2015;6. https://doi.org/10.3389/fphys.2015.00174.

53. Leonard TR, Herzog W. Regulation of muscle force in the absence of actin-myosin-based crossbridge interaction. Am J Physiol Cell Physiol 2010;299:Accentuated eccentric loading and cluster set configurations in the bench press. 2020. doi: 10.1519/JSC.0000000000003664. https://doi. org/10.1152/ajpcell.00049.2010.

54. Nishikawa KC, Monroy JA, Uyeno TE, Yeo SH, Pai DK, Lindstedt SL. Is titin a 'winding filament'? A new twist on muscle contraction. Proc $R$ Soc $B$ Biol Sci 2012;279:981-90. https://doi.org/10.1098/ rspb.2011.1304.

55. Bobbert MF, Gerritsen KGM, Litjens MCA, Van Soest AJ. Why is countermovement jump height greater than squat jump height? Med Sci Sports Exerc 1996;28:1402-12.

56. Komi PV, Bosco C. Utilization of stored elastic energy in leg extensor muscles by men and women. Med Sci Sports 1978;10:261-5.

57. Munger CN, Archer DC, Leyva WD, Wong MA, Coburn JW, Costa PB, et al. Acute Effects of Eccentric Overload on Concentric Front Squat Performance. $J$ Strength Cond Res 2017;31:1192-7. https://doi. org/10.1519/JSC.0000000000001825.

58. Comparison of muscle force production using the Smith machine and free weights for bench press and squat exercises. J Strength Cond Res 2005 19(1):169-176.

59. Merrigan JJ, O'Toole KB, Wutzke CJ, Jones MT. A Kinetic and Kinematic Analysis of Various Drop Jump Performances in Army Reserve Officer Training Corps Cadets 2021; doi: 10.1519/JSC.0000000000004041.

60. Wagle JP, Cunanan AJ, Carroll KM, Sams ML, Wetmore A, Bingham GE, et al. Accentuated eccentric loading and cluster set configurations in the back squat: $A$ kinetic and kinematic analysis. J Strength Cond Res 2021;35(2):420-427.

61. Merrigan JJ, Jones MT. Acute inflammatory, cortisol, and soreness responses to accentuated eccentric loading using supramaximal concentric loads. J Strength Cond Res n.d.; J Strength Cond Res 2021;35:S107-S113. https://doi.org/10.1519/ JSC.0000000000004010.

62. Lates A, Anagnost N, Wagle JP, Taber CB. ACCENTUATED ECCENTRIC LOADING AND CLUSTER SET CONFIGURATIONS IN THE BENCH PRESS: A PRELIMINARY ANALYSIS 2018:6.

63. Taber CB, Morris JR, Wagle JP, Merrigan JJ. Accentuated Eccentric Loading in the Bench 
Press: Considerations for Eccentric and Concentric Loading. Sports 2021;9:54. https://doi.org/10.3390/ sports9050054.

64. Chapman D, Newton M, Sacco P, Nosaka K. Greater Muscle Damage Induced by Fast Versus Slow Velocity Eccentric Exercise. Int J Sports Med 2006;27:591-8. https://doi.org/10.1055/s-2005-865920.

65. Hunter AM, Galloway SD, Smith IJ, Tallent J, Ditroilo M, Fairweather MM, et al. Assessment of eccentric exercise-induced muscle damage of the elbow flexors by tensiomyography. J Electromyogr Kinesiol 2012;22:334-41. https://doi.org/10.1016/j. jelekin.2012.01.009.

66. Hyldahl RD, Hubal MJ. Lengthening our perspective: Morphological, cellular, and molecular responses to eccentric exercise. Muscle Nerve 2014;49:155-70. https://doi.org/10.1002/mus.24077.

67. Macgregor LJ, Hunter AM, Orizio C, Fairweather MM, Ditroilo M. Assessment of Skeletal Muscle Contractile Properties by Radial Displacement: The Case for Tensiomyography. Sports Med Auckl Nz 2018;48:1607-20. https://doi.org/10.1007/s40279018-0912-6.

68. Yarrow JF, Borsa PA, Borst SE, Sitren HS, Stevens BR, White LJ. Early-Phase Neuroendocrine Responses and Strength Adaptations Following Eccentric-Enhanced Resistance Training. J Strength Cond Res 2008;22:1205-14. https://doi.org/10.1519/ JSC.0b013e31816eb4a0.

69. Chen TC, Yang T-J, Huang M-J, Wang H-S, Tseng $\mathrm{K}-\mathrm{W}$, Chen $\mathrm{H}-\mathrm{L}$, et al. Damage and the repeated bout effect of arm, leg, and trunk muscles induced by eccentric resistance exercises. Scand J Med Sci Sports 2019;29:725-35. https://doi.org/10.1111/ sms.13388.

70. Merrigan JJ, Jones MT, Malecek J, Padecky J, Omcirk $\mathrm{D}, \mathrm{Xu} \mathrm{N}$, et al. Comparison of Traditional and RestRedistribution Sets on Indirect Markers of Muscle Damage Following Eccentric Exercise. J Strength Cond Res 2020;Publish Ahead of Print. https://doi. org/10.1519/JSC.0000000000003740.

71. Bridgeman LA, Gill ND, Dulson DK, McGuigan MR. The Effect of Exercise-Induced Muscle Damage After a Bout of Accentuated Eccentric Load Drop Jumps and the Repeated Bout Effect: J Strength Cond Res 2017;31:386-94. https://doi.org/10.1519/ JSC.0000000000001725.

72. Bartolomei S, Totti V, Nigro F, Ciacci S, Semprini G, Michele RD, et al. A Comparison Between The Recovery Responses Following an Eccentrically Loaded Bench Press Protocol Vs. Regular Loading in Highly Trained Men. J Hum Kinet 2019;68:59-67. https://doi.org/10.2478/hukin-2019-0056.

73. Walker S, Häkkinen K, Haff GG, Blazevich AJ, Newton RU. Acute elevations in serum hormones are attenuated after chronic training with traditional isoinertial but not accentuated eccentric loads in strength-trained men. Physiol Rep 2017;5:e13241. https://doi.org/10.14814/phy2.13241.

74. Takada S, Okita K, Suga T, Omokawa M, Kadoguchi
T, Sato T, et al. Low-intensity exercise can increase muscle mass and strength proportionally to enhanced metabolic stress under ischemic conditions. J Appl Physiol 2012;113:199-205. https://doi.org/10.1152/ japplphysiol.00149.2012.

75. Linnamo V, Pakarinen A, Komi PV, Kraemer WJ, Kkinen $\mathrm{KH}$. Acute hormonal responses to submaximal and maximal heavy resistance and explosive exercises in men and women. J Strength Cond Res 2005; 19(3):566.

76. Lu SS, Lau CP, Tung YF, Huang SW, Chen YH, Shih $\mathrm{HC}$, et al. Lactate and the effects of exercise on testosterone secretion: evidence for the involvement of a cAMP-mediated mechanism. Med Sci Sports Exerc 1997;29:1048-54. https://doi.org/10.1097/00005768199708000-00010.

77. Ratamess NA, Kraemer WJ, Volek JS, Maresh CM, Van Heest JL, Rubin MR, et al. Effects of Heavy Resistance Exercise Volume on Post-Exercise Androgen Receptor Content in Resistance-Trained Men. Med Sci Sports Exerc 2004;36:S238.

78. Kraemer WJ, Gordon SE, Fleck SJ, Marchitelli LJ, Mello R, Dziados JE, et al. Endogenous anabolic hormonal and growth factor responses to heavy resistance exercise in males and females. Int J Sports Med 1991;12:228-35. https://doi. org/10.1055/s-2007-1024673.

79. Yarrow JF, Borsa PA, Borst SE, Sitren HS, Stevens BR, White LJ. Neuroendocrine Responses to an Acute Bout of Eccentric-Enhanced Resistance Exercise. Med Sci Sports Exerc 2007;39:941-7. https://doi. org/10.1097/mss.0b013e318043a249.

80. Crewther B, Cronin J, Keogh J, Cook C. The Salivary Testosterone and Cortisol Response to Three Loading Schemes. J Strength Cond Res 2008;22:250-5. https://doi.org/10.1519/JSC.0b013e31815f5f91.

81. Douglas J, Pearson S, Ross A, McGuigan M. Effects of Accentuated Eccentric Loading on Muscle Properties, Strength, Power, and Speed in Resistance-Trained Rugby Players: J Strength Cond Res 2018;32:275061. https://doi.org/10.1519/JSC.0000000000002772.

82. Harden M, Wolf A, Evans M, Hicks KM, Thomas K, Howatson G. Four weeks of augmented eccentric loading using a novel leg press device improved leg strength in well-trained athletes and professional sprint track cyclists. PLOS ONE 2020;15:e0236663. https://doi.org/10.1371/journal.pone.0236663.

83. Hortobágyi T, Devita P, Money J, Barrier J. Effects of standard and eccentric overload strength training in young women: Med Sci Sports Exerc 2001:1206-12. https://doi.org/10.1097/00005768-200107000-00020.

84. Aagaard P. Training-Induced Changes in Neural Function. Exerc Sport Sci Rev 2003;31:61-7.

85. Liu C, Chen C-S, Ho W-H, Füle RJ, Chung P-H, Shiang T-Y. The Effects of Passive Leg Press Training on Jumping Performance, Speed, and Muscle Power: J Strength Cond Res 2013;27:1479-86. https://doi. org/10.1519/JSC.0b013e31826bde9f.

86. Douglas J, Pearson S, Ross A, McGuigan M. Chronic Adaptations to Eccentric Training: A Systematic 
Review. Sports Med 2017;47:917-41. https://doi. org/10.1007/s40279-016-0628-4.

87. Bridgeman LA, McGuigan MR, Gill ND. A case study investigating the effects of an accentuated eccentric load drop jump training program on strength, power, speed and change of direction 2020:4.

88. Munger CN. Short Term Effects of Eccentric Overload Versus Traditional Back Squat Training on Strength, Power and Speed. Ph.D. New Mexico State University, 2020.

89. Suchomel TJ, Wagle JP, Douglas J, Taber CB, Harden M, Haff GG, et al. Implementing Eccentric Resistance Training-Part 1: A Brief Review of Existing Methods. J Funct Morphol Kinesiol 2019;4:38. https://doi. org/10.3390/jfmk4020038.

90. Suchomel TJ, Wagle JP, Douglas J, Taber CB, Harden M, Haff GG, et al. Implementing Eccentric Resistance Training_Part 2: Practical Recommendations. J Funct Morphol Kinesiol 2019;4:55. https://doi.org/10.3390/ jfmk4030055.

91. Harden M, Wolf A, Russell M, Hicks KM, French D, Howatson G. An Evaluation of Supramaximally Loaded Eccentric Leg Press Exercise: J Strength Cond Res 2018;32:2708-14. https://doi.org/10.1519/ JSC.0000000000002497.

92. Ojasto T, Häkkinen K. Effects of Different Accentuated Eccentric Loads on Acute Neuromuscular, Growth Hormone, and Blood Lactate Responses During a Hypertrophic Protocol. J Strength Cond Res 2009;23:946-53. https://doi.org/10.1519/ JSC.0b013e3181a2b22f.

93. Seitz LB, de Villarreal ES, Haff GG. The Temporal Profile of Postactivation Potentiation Is Related to Strength Level. J Strength Cond Res 2014;28:70615. https://doi.org/10.1519/JSC.0b013e3182a73ea3.

94. Suchomel TJ, Sato K, DeWeese BH, Ebben WP, Stone $\mathrm{MH}$. Potentiation Following Ballistic and Nonballistic Complexes: The Effect of Strength Level 2016. https:// doi.org/info:doi/10.1519/JSC.0000000000001288. 